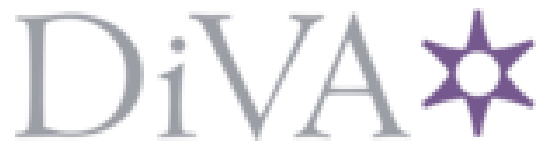

http://www.diva-portal.org

Preprint

This is the submitted version of a paper published in Peace and Change.

Citation for the original published paper (version of record):

Kreutz, J. (2018)

New Rebels in Postconflict Settings: The Principal-Agent Dilemma of Peacebuilding Peace and Change, 43(2): 218-247

Access to the published version may require subscription.

N.B. When citing this work, cite the original published paper.

Permanent link to this version:

http://urn.kb.se/resolve?urn=urn:nbn:se:uu:diva-349276 


\title{
New Rebels in Postconflict Settings The Principal-Agent Dilemma of Peacebuilding
}

\author{
Joakim Kreutz* \\ Department of Political Science, Stockholm University \& \\ Department of Peace and Conflict Research, Uppsala University
}

April 17, 2018

Full citation:

Kreutz, Joakim (2018) "New Rebels in Postconflict Settings: The PrincipalAgent Dilemma of Peacebuilding", Peace 83 Change 43(2): 218-247.

\begin{abstract}
This article explores the processes that lead to different types of civil war outbreak in postconflict societies, combining quantitative analysis with case studies of Myanmar and Sierra Leone to disaggregate situations in which former rebels resume fighting from those when new rebels emerge in the postconflict environment. The analysis, based in principal-agent theory, illuminates how relations between the government and exrebel elites, group cohesion among rebels, and the relationship between the government and the excombatants all can lead to resumed civil war. Its findings suggest that victories and settled conflicts are the most important outcome for preventing conflict recurrence by former rebels, but do not prevent the rise of new insurgencies. Moreover, the absence of government repression emerges as the factor most likely to reduce the risk of new rebellion.
\end{abstract}

*I acknowledge the support from the Swedish Research Council grant 2016-05734, and for the fieldwork in Myanmar Riksbankens Jubileumsfond grant M10:0100:1. 


\section{Introduction}

A common feature in many postcivilwar societies is that the end of war does not necessarily mean the end of violence. In many instances, the main threat consists of poorly disciplined excombatants or opportunistic criminals rather than battles between the formerly warring sides (Call and Stanley 2001; Autesserre 2010; Boyle 2014). Yet few studies on postconflict societies have explored the role of new actors in postconflict violence, as the main assumption in the peacebuilding literature is that only the parties involved in the first episode of fighting constitute a risk to take up arms again (Hartzell and Hoddie 2003; DeRouen and Bercovitch 2008; Walter 2009; Toft 2010; Caplan and Hoeffler 2017). Indeed, even studies focusing on civil conflicts featuring multiple rebel organizations assume that all actors are present already during the first phase of fighting (Nilsson 2008; Olson Lounsbery and Cook 2011; Driscoll 2012; Zeigler 2015; Rudloff and Findley 2016).

I contend that reasons for civil war recurrence should be sought not only among the features of the preceding fight but also in the postconflict society. This discernment should influence which specific actors are involved in the subsequent round of fighting that ends the peace. Postconflict societies encapsulate three different relational interactions whose breakdown can lead to resumed conflict: relations between former warring sides, cohesion among rebels, and relations between the government and excombatants. Drawing on principal-agent theory, which holds that elites (principals) rely on institutional structures to control the behavior of local agents (Eisenhardt 1989; Mitchell 2004), I argue that the process of peacebuilding includes a dilemma wherein reducing the risk of one type of recurrence unavoidably increases the risk of another. For example, warring parties' ability to credibly commit to an agreement implies that they effectively exercise control over former combatants (Walter 2002). Maintaining these types of organizational structures, however, undermines necessary efforts to reestablish state legitimacy over the use of force (Mason et al. 2011). If rebel forces are instead disbanded, then leaders cannot guarantee that their exfollowers will behave in accordance with the terms of the agreement (Pearlman 2009; Reiter 2016), hence the principal-agent dilemma; the risk of conflict recurrence exists in both settings, but the pathways to violence differ.

This study introduces new data on the identity of rebel organizations involved in civil war recurrence in the period between 1946 and 2013, separating formerly active rebels and new rebel groups. Adding information about who fought in the recurrence challenges several findings in the literature about how postconflict stability is created. This expanded analysis reveals that settling the issue that spurred the initial conflict bears significantly upon the prevention of conflict recurrence by exrebels. In preventing the rise of new insurgencies, however, the settlement of the original conflict issue has a much smaller effect. Democracy is shown to be of some importance when it comes to preventing the 
formation of new rebel groups in a postconflict society, but the most influential factor for renewed rebellion is government respect for human rights.

\section{Theory}

I begin by informally sketching a model of the key relational structures in postconflict societies and identifying how the breakdown of each leads to a different type of conflict resumption.

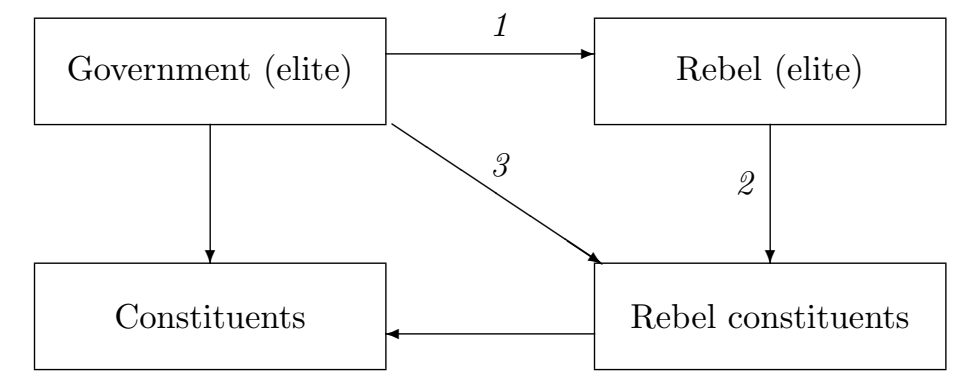

Figure 1: Three main challenges in post-conflict societies

\subsection{Postconflict challenges}

Consider a country at the end of armed conflict between government forces and a rebel movement. Suppose that fighting has been underway for some time, availing both sides some capacity and support to continue. The nonelite members of a community that contributed in some way to the start of the conflict (excombatants and supporters) are termed "rebel constituents" while citizens who did not contest the government (at least not openly) are called "constituents." In general, rebel constituents are vulnerable to repression in a postconflict society, but they also have experience in organizing rebellion, giving them greater agency for the option of resuming war (Jha and Wilkinson 2012; Nussio and Oppenheim 2014).

The first relational challenge in peacebuilding can be found in the interactions between the government and the rebels - as represented by their respective elites ( 1 in Figure 1). To end conflict, one party must decide to end its use of force following an offer of concessions or low capacity for continued fighting 
(Mason and Fett 1996; Kreutz 2010).In the postconflict society, actors may reconsider this decision and take up arms again following discord among the elites, or change in parties' relative strength convinces one actor of having a greater chance of victory in a second round of fighting (Werner 1999). This means resumption of the old conflict.

After rebel elites have decided to end fighting, a second relational challenge emerges in determining whether and how to maintain control over its constituency of combatants and supporters (2 in Figure 1). Scholars have recently emphasized that fighters in civil conflicts often lack discipline during the war (Kalyvas 2003; Weinstein 2006; Butler, Gluch and Mitchell 2007; Carey, Colaresi and Mitchell 2015), and have asserted that this problem should be even more prominent in the postconflict society. As the struggle against the government ends, the explicit political purpose for the organization is gone along with the means developed during the conflict to uphold discipline among its members. Such disciplinary structures include institutional arrangements like de facto "courts" or the less formalized systems of discipline and control, which are expected to be discontinued as legitimate authority is transferred toward state institutions as part of the conflict termination process (Mampilly 2011; Sanín and Wood 2014). Consequently, internecine struggles are more likely at the end of a conflict as disagreements with the peace terms can give rise to the emergence of spoilers (Stedman 1997; Pearlman 2009; Olson Lounsbery and Cook 2011). Further, the dismantling of control structures opens opportunities for individual agents to defect from their groups (Gates 2002; Vinci 2006). This breakdown in cohesion can derail the peace in two ways: by incentivizing elites to mobilize their existing organization to resume fighting to sustain support of their constituency, or by motivating former rankandfile members to form new breakaway rebel groups (Atlas and Licklider 1999; Driscoll 2012).

The third relational challenge in a postconflict society also involves the former rebel rank and file, but in terms of their interaction with the government (3 in Figure 1). A crucial aspect of successful peacebuilding after civil war is to reintegrate the citizens who fought against the government in wartime into the nation's peacetime society. To do this, exrebels must begin to place greater trust in public institutions than in the nonstate networks they relied on during the conflict (Tilly 2005). Former members of the rebel constituency have fewer previous experiences (with perhaps no positive ones) of interacting with the state, yet as noted above, they maintain the option of rejecting this process due to their welldeveloped wartime skills for armed resistance against perceived "bad governance" (Walter 2015). ${ }^{1}$

\footnotetext{
${ }^{1}$ It could be argued that a fourth pathway to war in post conflict countries is when a completely new group emerges inside the government constituency, or because of inter constituency clashes. In going through the cases, though, I found that almost no cases of recurrence were completely without a link to earlier rebels, as such strains more commonly result in non violent protests or rioting. See for example Boyle (2014) and Matanock and García-Sánchez (2017).
} 


\subsection{Interelite explanations for conflict recurrence}

The conflict recurrence literature is dominated by studies that see armed conflict as a bargaining game in which the processes leading up to war have a direct influence on both how it ends and why it may recur (Walter 2009). This conception of the causal relationship between the outbreak of war and the subsequent structures of peace suggests that the risk for resumption of conflict is greater when the relative strength of the parties remains undetermined, which implies that conflicts ending in a decisive victory for the militarily dominant "winning side" can be expected to yield greater postconflict stability (Licklider 1995; Quinn, Mason and Gurses 2007; Toft 2010; Mason et al. 2011).

A competing argument holds that a peace agreement is the most sustainable termination of a conflict, as this provides a solution embraced by the political leaders of both formerly opposing forces. The risk of recurrence after an agreement is due to the credible commitment problem (Walter 2002; Driscoll 2012). Fighting resumes because parties find it difficult to convincingly signal that they will not renege on their part of the settlement as soon as the other side has demobilized (Quinn, Mason and Gurses 2007). To overcome the credible commitment problem, scholars have suggested that parties should share power after the agreement or that the process is monitored by third parties (Hartzell and Hoddie 2003; Fortna 2004).

\subsection{The Principal-Agent Dilemma of Peacebuilding}

After the fighting between warring sides has ended, bargaining theory can no longer fully account for all of the factors that may incite renewed violence involving former combatants. While the transition to peace is likely to be facilitated by effective control of the former rank and file, maintaining these organizational structures - both formal and informal - means that wartime divisions continue to influence postconflict politics indefinitely. Whether to maintain or dismantle wartime institutions for the sake of postconflict stability is a dilemma that is inherent within the structure of peacebuilding. It is generally held that longterm peace after a victory or peace agreement depends on the reimposition of a state monopoly of violence, which is achieved by demobilizing the losing/nonstate actor. However, this process is undermined by its own progress as the elites of warring organizations gradually lose their ability to exert authority over former subordinates.

Principal-agent theory provides the clearest explanation of this conundrum within the resolution of civil conflicts. This approach emphasizes how a decision maker (the principal) has to delegate responsibility to subordinates (the agents) to implement a given decision (Eisenhardt 1989). In a civil war, rebel 
elites delegate the actual fighting to their lowerlevel commanders and rankandfile soldiers (Gates 2002). The agents of the conflict have more information about the ontheground situation as well as specific skills fit for purpose, which means they have an opportunity to select to what extent they will follow the given orders from above. This dynamic has been found to influence the use of violence by armed groups in civil conflict, in particular with regard to the incidence and severity of human rights violations (Mitchell 2004). While principals may proclaim certain rules of engagement for their fighting forces, their agents interpret these in light of their own local aims and may therefore commit atrocities without having been instructed to do so. Consequently, to control the agents and assure command, principals establish institutions within their organizations through which they can monitor the behavior and punish agents for disobedience (Vinci 2006).

However, at the end of conflict, rebel elites are denied access to many of the structures they used for controlling their forces, ranging from such rhetorical tools as invoking a shared "struggle" to coercion in the form of the threat of violent punishment. Absent the unifying mission of political rebellion and faced with uncertain prospects in the postconflict society to come, former fighters may opt to defect from the peace process and join, or form, another armed group (Kydd and Walter 2002; Pearlman 2009). It is also worth remembering that excombatants, even after demobilization, retain the knowledge and experience in organizing for conflict, making the formation of another armed rebel organization less risk filled than what would be the case for a citizen who had never participated in armed political rebellion (Nussio and Oppenheim 2014).

Merely having the opportunity to leave their former group is, however, not a sufficient condition for reigniting civil conflict. Even if the end of conflict means that excombatants suffer economically, socially, or politically, this is more likely to incentivize them to criminality than to renewed rebellion. The treatment that former rebels receive by the state is a crucial determinant in whether excombatants choose to take up arms after a conflict has been brought to an end. The starting point for relations between the government and the citizens who recently waged war against it is certainly not one of great trust and optimism. However, while one part of postcivil conflict peacebuilding aims to undermine the rebel group and its related structures, the other part seeks to involve former combatants in establishing a new state-citizen contract.

Tilly (2005) interprets these relations as a process of state formation in which governing institutions take an expanding role in citizens' trust networks, and ideally overtake systems and structures that are tied to the former warring organization. In Trust and Rule, Tilly $(2005,44)$ asserts that trust networks are "named, bounded, internally communicating sets of relations entailing mutual obligations" which (if they include state institutions) provide the "contingent consent" that makes citizens comply with costly demands made by government and thus facilitate improved institutional performance (Levi 1997). All individ- 
uals are part of, and all communities and societies consist of, different types of trust networks. Political and state institutions, however, may or may not exist outside of them. Trust networks with no or few links to state institutions may be largely neutral on political matters and based around, for example, kinship and religion, but networks may also actively undermine the ability of the state to govern. Such networks consist in particular of nonstate governance structures that compete with official institutions to improve on the perceived weak capacity or willingness of the state to provide security, justice, or economic development for a community. The presence of such statecompeting networks is a defining characteristic of civil conflicts, where a central objective of most armed actors is to coopt or create social, political, and economic networks to bolster their legitimacy and base of support. At the end of the conflict, the challenge for the state becomes persuading citizens (both excombatants and others) to place greater trust in public institutions than in what remains of these conflict networks.

\subsection{Implications}

This examination of the principal-agent dilemma in postconflict peacebuilding illuminates trends in the transition from war to peace that influence who becomes involved in restarting civil war in a postconflict society. It can be expected that the more control the principals have over their agents, the greater the likelihood that a breakdown of interelite relations will cause a recurrence of hostilities. In contrast, new fighting involving a new rebel organization should be more likely in situations in which former leaders have lost control over the behavior of their former agents (Weinstein 2006; Staniland 2014; Balcells and Kalyvas 2014).

The second implication of this argument is that government policy has a greater, more direct influence upon the emergence of new grievances in the postconflict environment upon the implementation of the peace terms. This differs from the literature on civil war recurrence, which assumes that the presence of spoilers is a consequence of discontent with the decision to end the initial conflict (Stedman 1997). However, postconflict societies may have many political and social problems that are not related to the previous fighting or that were embedded in the goals of the previous rebellion. Beyond making the implementation of peace agreements more difficult, an absence of democracy and equality in a country can be the motivation for a new rebellion (Walter 2015; Cederman, Gleditsch and Buhaug 2013). This is, however, expected to motivate new rebellions rather than galvanizing former rebel elites who at the cessation of the initial fighting may have joined the ruling elite or its patronage structures. 


\section{Research design}

\subsection{Data}

Civil conflict data are taken from internal and internationalized internal armed conflict in the UCDPPRIO Armed Conflict Dataset (Gleditsch et al. 2002; Themnér and Wallensteen 2014). This reflects instances of fighting between the government of a state and an organized armed challenger over a political incompatibility (control over government or territory) that caused at least twentyfive battlerelated deaths in a year. To identify start, end, and recurrence of conflicts, I use conflict episodes from the 42014 update of the UCDP Conflict Termination data set covering 1946-2013 (Kreutz 2010). The structure of the data set is postconflictyear, meaning that each observation represents a year after the termination of an intrastate armed conflict until fighting resumes over the same incompatibility.

\subsection{Dependent variable}

The crucial information about the dependent variable in this study is whether the resumption of a conflict involves old unchanging belligerents or one or more new actor(s). The warring parties are categorized as "old" or "new" actors based on their organizational identity and their involvement in the initial conflict over the course of its final year. An "old actor" is one that stays relatively consistent in its organization and structure from the conclusion of combat operations through to the outbreak of renewed civil warfare. Further, if a group merely has changed its name or leadership in the time between the end of the first conflict and recurrence, it is still considered an "old actor." I assume that the government remains a consistent actor, regardless of whether there has been incumbency change since the previous conflict ${ }^{2}$

The classification of a "new actor" denotes the groups that either consist of former members of another, preceding, rebel group (such as a splinter group) or that are completely new organizations in the sense that they previously had not been involved in conflict activity. In cases where multiple rebel organizations were active at the end of the initial conflict and any of them were involved in the conflict recurrence year (as well as new actors), I code conservatively that the resumption involves an old actor.

\footnotetext{
${ }^{2}$ With one exception: if the preceding conflict ended with a rebel victory and regime takeover, then a resumption involving old actors constitutes the launch of a rebellion by the previous government side. For example, the Taliban constituted the government side in Afghanistan before their 2001 removal, yet when they resumed conflict against the Afghan government in 2003 it is registered as an old actor relapse. More information about coding definitions and decisions is available in the appendix.
} 
The analysis consists of a total of 385 unique conflict terminations, of which 198 (51.4 percent) resumed at some point in time. The most prominent means of resumption involve old rebels, which occur in 110 instances (55.6 percent). Consequently, there are eightyeight observations of a second conflict involving new combatants.

\subsection{Independent variables}

Variables expected to provide information about the risk of recurrence involving the old opposition elites include the outcome of the initial conflict. I indicate whether fighting ended through a victory or the signing of a peace agreement (Kreutz 2010). Negotiated settlements may include features intended to overcome the risk of interelite tensions and offer a process for dismantling former rebel organizational structures. The first is most commonly pursued through the imposition of political power sharing (Hartzell and Hoddie 2003), which could be expected to decrease the risk of former rebels instigating a recurrence. If the conflict was over government, I code power sharing when rebels became part of the postconflict central government, while after territorial conflicts rebels are coded as participating in power sharing if they had access to central power, local autonomy power, or both. To help dismantle former combatant organizational structures, peace agreements are often followed by a program to demobilize exrebels. My measure explicitly codes the presence of a demobilization program, in which some form of benefits (economic, training, etc.) were distributed as part of the demobilization process.

A weakness of the outcome information is its focus on events during the final months of the initial conflict as a determinant for postconflict stability. I therefore include an alternative measure to the peace agreement variable which offers a more qualitative assessment of the presence of unsettled conflict issues. This variable - settled conflict issue - combines the observations when (1) a peace agreement led to the termination of conflict, with (2) after a peace agreement was signed by the initial warring sides at some point later in the postconflict period, or (3) after the warring sides publicly announced that the issue at the heart of the initial conflict has been settled. One example of the latter is Ethiopia's recognition of independent Eritrea in 1993, even though the initial separatist civil conflict is coded as ending with a military victory.

The second cluster of variables focuses on measures that indicate the cohesion of the former rebel group. A prime indicator of organizational capability is that a group has managed to maintain rebellion for a certain time (Gates 2002). As successful rebel institutions are selfsustaining, the critical cutoff should occur relatively quickly. I define long war as the cases in which the duration between the first death and the end of conflict is two years or longer. A second indicator of rebel group institutionalization is its ability to mobilize fighters (Quinn, 
Mason and Gurses 2007). Groups that at the end of the civil conflict consist of at least two thousand fighters are defined as forming a large rebellion, based on data collected for this study. Third, rebels with support from an outside country are provided with additional resources and advisers that should provide more organizational stability (Karlén 2017). For rebel external support information, I rely on the UCDP external support data set (Hogbladh, Pettersson and Themnér 2011).

The third cluster of variables focuses on the conflict context, in which groups that are faced with more competition in their recruitment efforts are expected to use more resources to foster cohesion and internal control. In addition to settings with multiple rebel dyads, such competition can also come from the presence of progovernment militias. Data on the number of active rebel groups is drawn from the UCDP conflict data set, along with data on militias from the progovernment militia project (Carey, Mitchell and Lowe 2013).

The last cluster of independent variables focuses on state policies that may foster or undermine relations between former rebels and the state. This includes whether the government is a consolidated democracy (at least 6 on the Polity IV scale)(Marshall, Jaggers and Gurr 2014), whether it discriminates against at least a third of its population (Vogt et al. 2015), or whether it is repressive (one standard deviation below global mean of the latent human rights score) Fariss (2014). Finally, I include an indicator of whether a country is an oil exporter as natural resources has been found to encourage state patronage and incentivize rebellion (Ross 2012).

All estimations control for the type of conflict (over government or territorial aims), the presence of a U.N. peacekeeping operation in the country, GDP per capita (Gleditsch 2002), and a logtransformed measure of country population Dahlberg et al. (2015). For the multinomial logit estimations, I also control for time in the form of peace years, as well as its squared and cubed terms (Carter and Signorino 2010).

\subsection{Statistical technique}

Postconflict stability can be measured through two different approaches, and this study employs both in separate estimations. The first consists of measuring the time between the end of conflict and the resumption of fighting after a period of peace, if such a recurrence happens at all. This can be estimated by a socalled survival model, which relates the time that passes until fighting is observed again to covariates that indicate the likelihood (hazard) that this occurs. For postconflict societies that do not experience renewed conflict, the last observation is the year 2013 and remaining years are rightcensored. I first present a Cox proportional hazards model with peace years (the years between 
the end of previous conflict and the start of a new conflict) as the unit of analysis and the year of recurrence involving any actor as the dependent variable (Lin and Wei 1989). The Cox regression is beneficial as it does not assume that the baseline hazard follows a particular form, meaning that it is not sensitive for the potential risk that conflict recurrence increases over time (due to, e.g., less war fatigue) or decreases over time (due to, e.g., improved state capacity). A problem with the Cox model, however, is that the dependent variable indicates only when fighting is observed in a postconflict society but not whether this involves old or new actors. For this, I instead explore postconflict duration of peace using a competing risk proportional hazards model (Fine and Gray 1999). With this technique, the risk of recurrence by old rebels is interpreted primarily in relation to the risk of fighting with new rebels and vice versa.

The second empirical approach is more appropriate for studying the different risks for old and new rebels to be involved in fighting, but is less precise in handling the temporal dimension of postconflict peace. This uses a dependent variable that contains information of recurrence or not, and whether it involved (1) old rebels or (2) new rebels. This constitutes a categorical but unordered variable, making multinomial logit (MNL) an appropriate technique (Long and Freese 2006). MNL compares all possible outcomes for the dependent variable and requires that one category serves as the reference category, for which all coefficient estimates are set to zero for standardization purposes. To explain civil war recurrence, the logical baseline category is "no recurrence" while the results of the remaining two options are presented as relative to this baseline. If the alternative pathways to recurrence have some common determinants, the MNL identifies these better than a regular probit or logit model. A weakness of MNL is that the random disturbance terms for every alternative are identically and independently distributed in accordance with the extreme value distribution. This assumption (independence of irrelevant alternatives) is primarily a problem if the outcomes can be viewed as not independent by the decision maker. As this study specifies decisions by different actors rather than different choices by a specific actor, MNL is appropriate (Small and Hsiao 1985). Besides a normal MNL, I also estimate twolevel multinomial logistic models with shared random effects. This makes it possible to explore whether rebel organizational features (1) lead to certain conflict outcomes and postconflict policies, or whether conflict outcomes (2) lead to certain postconflict state policies. ${ }^{3}$

\footnotetext{
${ }^{3}$ See more information about the models and output in appendix.
} 


\section{Results}

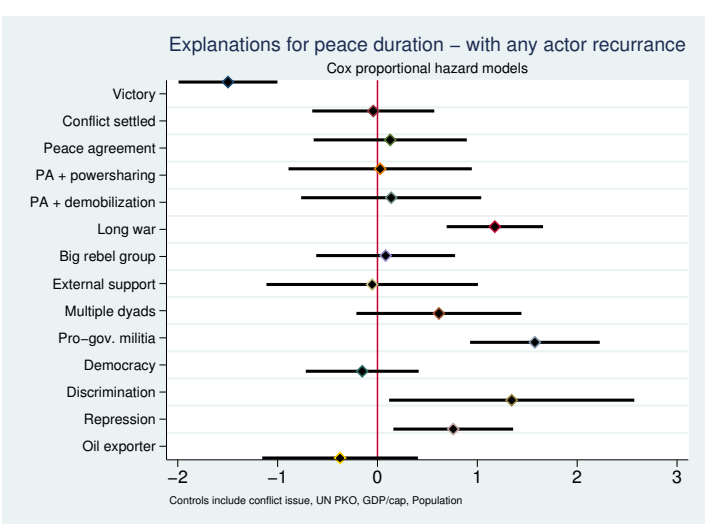

(a) Any actor recurrence



(b) Old actor recurrence

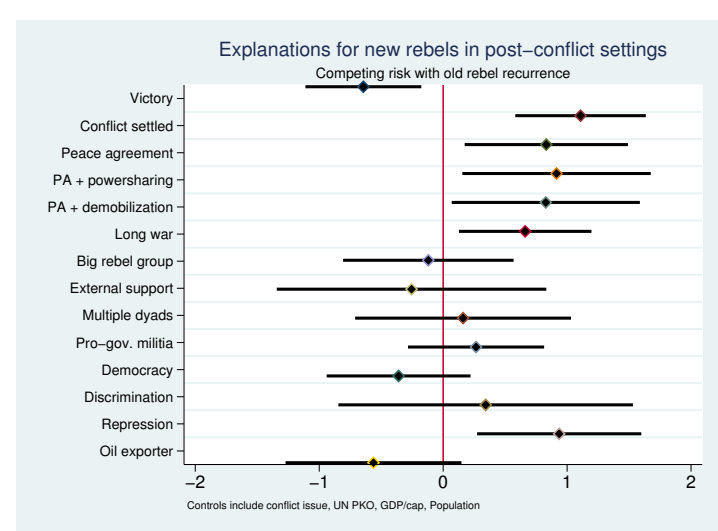

(c) New rebels in post-conflict settings

Figure 2: Explainations for peace duration 
To visualize the contribution of disaggregating who is involved in civil war recurrence, the findings should be compared with a model in which the dependent variable is recurrence by any actor. Figure $2 \mathrm{~A}$ presents the findings from a series of Cox estimations on any recurrence using robust standard errors clustered by country, controlling for conflict issue, U.N. peacekeepers, GDP per capita, and population. Very few of the variables are statistically significant at the 0.05 level or above as indicated by the lines that cross zero. Victories are followed by a longer peace duration, while long wars, progovernment militia presence, discrimination, and repression shorten peace duration. ${ }^{4}$ When the CIF is greater than zero, then there is an increased risk of recurrence for that actor relative to the other.

Starting with the variables that make recurrence by old rebels more likely than the emergence of new rebel movements, the findings show that a clear conflict outcome is preferred to conflict that just fizzles out through low activity (Kreutz 2010). Recurrence by old actors happens later, if at all, after a decisive victory or when the conflict issue has been settled in some form, but not solely through a peace agreement signed at the end of fighting. This indicates that there may be advantages when peace talks continue for some time in the postconflict environment rather than having to be concluded at the time that the fighting ceases. A general feature of situations when the conflict issue has been settled is that they primarily reduce the risk of a conflict recurrence involving old actors. This corresponds to findings in previous research that agreements signed by some but not all rebel sides are likely to end the fighting efforts by the signatories but not the nonsignatories (Nilsson 2008). Mirroring this finding, Figure $2 \mathrm{C}$ shows that new rebels are more likely to appear after peace agreements have been reached. When looking at specific postconflict management efforts, the risk that former rebels resume fighting is not decreased following demobilization efforts or power sharing. A possible explanation for this is that the content of these measures may make them sometimes more difficult to implement and thus create disaffection among former rebels (DeRouen Jr, Lea and Wallensteen 2009).

Two findings are consistent for the risk of both old rebels and new rebels that are involved in a recurrence after an ended conflict. First, recurrence is less likely following victory and, second, more likely if the initial civil conflict was long. These findings seem at odds with each other. The most common explanation for peace stability after victory focuses upon the victors' ability to dismantle the defeated forces, and this has been used as an argument to let the parties "fight it out" (Toft 2010). However, the challenge of demobilizing former armed opposition is more difficult when organizations have existed for a long time and become entrenched in local economic and social structures

\footnotetext{
${ }^{4}$ Mathematically, the CIF for the given type of relapse is a function of both causespecific hazards. The CIF begin at time zero and increase to an upper limit equal to the eventual probability that the event will take place, but this is not equal to one because of competing events.
} 
(Mampilly 2011; Staniland 2014). There are two ways that these findings can be reconciled: first, that victory does not mean that the defeated are completely crushed (Kecskemeti 1958; Hartzell 2009), and second, that multicollinearity exist between these two variables, meaning that victories occur primarily in short conflicts (de Rouen Jr and Sobek 2004). Figure 3 indicates that the latter is the case, showing the kernel distribution in a comparison of conflict duration for victory and peace agreements. As peace agreements are reached primarily in longerrunning conflicts and thus in societies in which there are greater challenges to establish stability, the seemingly stabilizing effect of victories is at least in part a consequence of their occurrance (most commonly) in the first or second year of fighting.

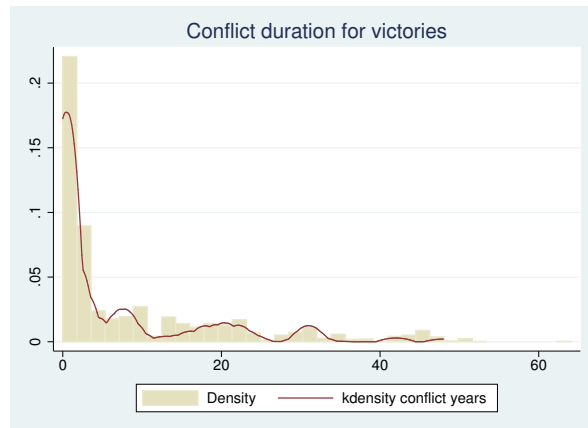

(a) Victory

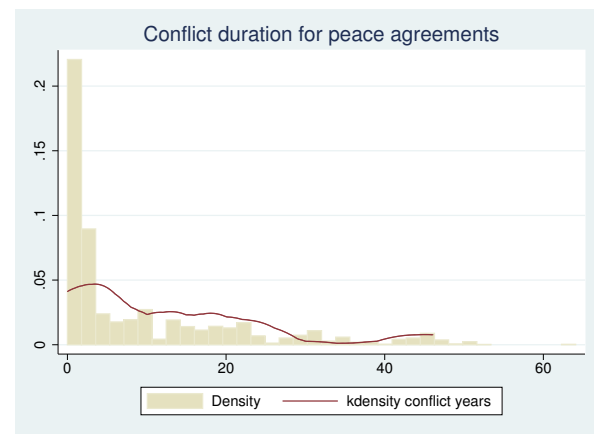

(b) Peace agreement

Figure 3: Duration of conflict ending with victory or peace agreement

Figure 2B also shows a greater risk of recurrence by old rebel actors in civil conflicts with multiple actors, regardless of whether the multiple actors are other rebel factions (multiple dyads) or progovernment militias. This is to be expected as armed groups that operate in an environment that is highly competitive for members have perpetual incentives to improve institutional cohesion to avoid defection to other groups (Cunningham, Bakke and Seymour 2012; Nygård and Weintraub 2015).

Shifting the focus, finally, to government policy in postconflict societies, democracy does not in itself seem to be a necessity for peace stability. Former rebels are, however, more likely to resume fighting if the government pursues discriminatory policies in the postconflict environment. Particularly negative for peace stability, though, is when postconflict governments are repressive, as this increases the risk of both old rebels and new rebels taking up arms in a resumption of civil war. A possible explanation for the influence of discriminatory practices in a postconflict society is the literature about how repression can, under certain circumstances, incentivize mobilization into violent opposition (Lichbach 1987; Saideman and Zahar 2008). Postconflict societies may 
constitute one setting where this is more probable, as individuals with access to weapons and skilled in techniques of rebellion can be rapidly mobilized.

Table 1 presents another modeling strategy for estimations measuring the probability of different types of recurrence relative to the probability that a conflict does not recur in a given year. The coefficients need to be interpreted in relation to both continued peace and the alternative recurrence path so they cannot be used to account for the size of the effect, but negative values indicate a decreased probability and positive values an increased probability of recurring conflict. Model 1 presents a straightforward multinomial logit that compares the probability that old and new actors resume conflict in a given year compared with continued peace. Models 2 and 3 are estimated as twostage multinomial logits, using a structural equation modeling technique. This is intended to control for the possibility that as some variables constitute information about characteristics of the country or the initial conflict, these may systematically correlate with subsequent characteristics of the postconflict society. Twostage models account for this possible selection bias by estimating the effect of such temporally different factors separately. In Model 2, the first stage is used to see whether the presence of oil and the conflict characteristics systematically influences the type of outcome and postconflict policies pursued by a state. In Model 3, the first stage accounts for whether certain conflict outcomes systematically lead to certain postconflict policies such as democracy level or repressive policies. 
Table 1: Multinomial Logit Regressions of Disaggregated Types of Recurrence

\begin{tabular}{|c|c|c|c|}
\hline & $\begin{array}{c}(1) \\
\text { Mlogit }\end{array}$ & $\begin{array}{c}(2) \\
\text { Episode-Mlogit }\end{array}$ & $\begin{array}{c}3) \\
\text { Outcome-Mlogit }\end{array}$ \\
\hline \multicolumn{4}{|l|}{ Old rebels } \\
\hline Victory & $-1.522(-2.18)^{*}$ & $-2.359(-5.70)^{* * *}$ & \\
\hline Peace settlement & $-2.219(-3.20)^{* *}$ & $-1.880(-4.84)^{* * *}$ & \\
\hline Long war & $0.120(0.23)$ & & \\
\hline Large rebellion & $-0.102(-0.35)$ & & \\
\hline External support & $-0.0781(-0.12)$ & & \\
\hline Multiple dyads & $0.0979(0.18)$ & & \\
\hline Pro-gov. militia & $1.954(2.72)^{* *}$ & & \\
\hline Democracy & $0.384(1.00)$ & $0.339(1.19)$ & $0.135(0.49)$ \\
\hline Discrimination & $0.758(1.35)$ & $0.754(1.66)$ & $0.870(1.99)^{*}$ \\
\hline Repression & $-0.399(-0.82)$ & $0.363(1.23)$ & $0.313(1.08)$ \\
\hline Oilexporter & $0.134(0.36)$ & & \\
\hline Territory & $0.517(1.53)$ & $0.496(1.98)^{*}$ & $0.694(2.83)^{* *}$ \\
\hline \multicolumn{4}{|l|}{ New rebels } \\
\hline Victory & $-1.764(-2.56)^{*}$ & $0.0755(0.24)$ & \\
\hline Peace settlement & $0.202(0.35)$ & $0.723(2.06)^{*}$ & \\
\hline Long war & $-0.839(-1.65)$ & & \\
\hline Large rebellion & $-0.825(-1.90)$ & & \\
\hline External support & $-0.292(-0.31)$ & & \\
\hline Multiple dyads & $-0.499(-0.37)$ & & \\
\hline Pro-gov. militia & $-0.792(-1.56)$ & & \\
\hline Democracy & $-1.570(-2.98)^{* *}$ & $-0.502(-1.58)$ & $-0.294(-0.94)$ \\
\hline Discrimination & $-0.839(-0.71)$ & $-0.101(-0.16)$ & $-0.254(-0.40)$ \\
\hline Repression & $1.279(2.46)^{*}$ & $0.745(2.30)^{*}$ & $0.705(2.19)^{*}$ \\
\hline Oilexporter & $-0.154(-0.36)$ & & \\
\hline Territory & $-1.183(-2.33)^{*}$ & $-1.257(-3.87) * * *$ & $-1.365(-4.38)^{* * *}$ \\
\hline$N$ & 1891 & 3723 & 3723 \\
\hline
\end{tabular}


These estimations largely provide similar findings as the competing risk model reported before. The risk that old rebels resume conflict is lower after both clear victories and recognized conflict settlements, and this correlation has a higher statistical significance level in the twostage model. For new rebels, Model 1 shows a decreased risk of recurrence after victory, but this variable is no longer statistically significant in the twostage model where conflict characteristics - such as initial conflict duration - are better accounted for. The twostage model also shows that new rebellion is more likely if the previous conflict has been settled, in line with the argument that extremist groups may seek to undermine an agreement through the use of violence (Kydd and Walter 2002).

The earlier competing risk estimations showed that old rebels were more willing to resume conflict than new groups in a conflict setting with many rival factions, but the MNL does not find this. Only the presence of progovernment militias in the previous conflict increases the probability of old rebel recurrence with statistical significance at commonly accepted levels. Democracy has again shown little effect on postconflict stability, in contrast to repression, which increases the risk of new rebellions starting. ${ }^{5}$

Table 1 further reports the statistically significant finding regarding one of the control variables - whether the conflict issue related to government overthrow or territorial autonomy/secession. It shows that territorial conflicts are more likely to recur involving old actors but less likely to recur with new rebels in all estimations. The fact that new rebels are unlikely to emerge in territorial conflicts, which have been identified as more likely "internal armed rivalries" (DeRouen and Bercovitch 2008), is probably a consequence of the increased ability of local rebel elites to maintain control over their agents. Mobilization for a separatist goal is arguably easier to accomplish along the lines of established social networks (kinship, geographical proximity, social, and religious identities) that state structures have particular difficulty penetrating, making it harder to build a sustainable peace. Fighting may have ended, but communities remain antagonistic and former armed organizations remain influential in their capacity to resume the conflict in the future.

The multinomial logit estimations include controls for time, and these can be interpreted to provide information about how the risks of recurrence by different actors may change over the postconflict period. Figure 4 illustrates the respective risks of recurrence. Both types of recurrence decrease over time, which is in line with existing research. During the first eight to nine years after the end of conflict, there is an almost equal risk of recurrence by old rebels as by new rebels, but in subsequent years, the main risk of conflict is through the emergence of new rebellions in postconflict societies. This means that much of the theorizing in the literature on civil war recurrence has misperceived the

\footnotetext{
${ }^{5}$ In alternative estimations, democracy, discrimination and repression are not in the same model, with democracy and repressionproducing similar effects as in these models. The coefficient for discrimination is not statistically significant according to commonly accepted levels.
} 
phenomenon by measuring peace duration as determined by the bargaining between the government and former rebels. My findings suggest that when peace has lasted for around a decade, the most likely pathway to renewed fighting is by the emergence of a new rebel group, rather than a resumption of the initial conflict involving the same actors.



Figure 4: Relative risk of recurrence/actor: based on Table 1: Model 1.

\section{Case studies}

The findings from the statistical analysis challenge the interpretation of postconflict politics as only a bargaining game between former combatants. But is the argument that this occurrence of new rebel actors is because of a breakdown of principal-agent relations plausible? To illustrate this process, the next section describes how new actors grew in strength as a consequence of how rebel elites lost the ability to control their subordinates after a ceasefire in Myanmar 2012, and after a peace agreement in Sierra Leone 2001.

\subsection{Myanmar: The Shan states after a ceasefire}

The Shan states in Myanmar (Burma) are based in northeastern corner of the country bordering China, Laos, and Thailand. The region hosts a wide variety of ethnic groups, but the Shan insurgency began in 1958 following the removal of autonomy provisions for local princes and discontent with a decade of emergency rule resulting from clashes between the Myanmar army and Chinese Kuomintang remnants (Tun 2009). Throughout the conflict, the Shan insurgency had been highly factionalized with significant geographic overlap with other ethnic rebels 
(Kachin, Karenni, Kokang, Lahu, Palaung, Wa, and smaller groups), a communist insurgency, progovernment militias, and private armies of drug lords. The brief spells of a largely unified Shan insurgency were primarily in 1964-76 under the name Shan State Army and again in 1985-95 as the Mong Tai Army (MTA). After the leader of MTA, Khun Sa, surrendered to the government in January 1996, most of his rankandfile troops formed a new group generally referred to as Shan State Army-South (SSAS). The name distinguished them from Shan State Army-North (SSAN), which was a very small Communistallied faction who ended conflict through a 1989 ceasefire with the government (Lintner 1999; Shoke 1999).

In 2010-11, the military regime in Myanmar transferred power to a civiliandominated administration led by the former General Thein Sein. The political liberalization of the central government led to the removal of Western sanctions, and the new regime initiated talks with the many ethnic insurgencies. At the same time, government efforts to bring SSAN under Myanmar army control as a border guard militia, which became the Border Guard Forces, was rejected by a third of the group (some four hundred troops) who proclaimed a return to opposition (Interview 2010). Thus, the government was simultaneously exploring talks with the SSAS and launching offensives against this SSAN faction in adjoining areas. During this fighting in March 2011, some of the SSAN members who had accepted the Border Guard offer defected to join the rebel faction, who claimed to have grown to almost a thousand troops by the end of the year (Interview 2011b,a).

On December 2, 2011, the government and SSAS signed a ceasefire followed by a more substantial agreement on January 16, 2012, allowing the SSAS to keep their arms and to exercise limited local control by retaining the right to appoint village heads. On January 28, the SSAN also signed a ceasefire. Throughout the year, both ceasefires were repeatedly violated (BNI 2013) and were met with suspicion among rankandfile soldiers and local villagers (Interview 2012d,a). Many locals worried that the leadership of SSAS may have betrayed the Shan cause for personal gain, and they held concerns about their personal security. For example, a rebel soldier responded to the question whether he wanted to demobilize and take up civilian life by saying: "Never. I don't trust the army. I don't dare go to governmentcontrolled territory..." (Interview 2012b). Late 2012 brought reports of troops defecting from SSAS to work across the border in Thailand, as well as open opposition from some SSAS commanders about the ceasefire while SSAN troops secretly fought together with the nearby ethnic Kachin rebels (KIA) against the government (Interview 2012c).

Once government forces launched an offensive against the KIA headquarters in late December 2012, the ceasefire with SSAN soon collapsed as government troops entered SSAN territory in February 2013 (DVB 2013). Consequently, the conflict over the status of the Shan territory restarted, and the government offensives that followed were accompanied with violent repression of the 
local population (PWO 2013). After initial failed attempts to re establish the ceasefire, warfare continued in the ensuing years. Despite this ongoing fighting, SSAN military capacity steadily improved to an estimated eight thousand troops by 2016. During this time, SSAS maintained their ceasefire but many of their soldiers defected to the SSAN - sometimes in a concerted effort led by their local commanders - against the stated wishes of the SSAS elite (Interview 2013; BNI 2015). Throughout this period, there were persistent rumors in the region that SSAS commanders and the rank and file who fought with SSAN would be punished by SSAS, but there is no evidence that such measures have been carried out.

\subsection{Sierra Leone: After demobilization}

Civil war began in povertystricken Sierra Leone in 1991 when a small group of rebels entered the country from neighboring Liberia and began to recruit disenfranchised youth into the Revolutionary United Front (RUF). The rebellion was externally supported by Charles Taylor-leader of one of the competing factions over power in the neighboring Liberian civil war-and rapidly spread across Sierra Leone and its diamond mines (Richards 1996; Reno 2011). The group lacked a strong ideological commitment and was composed of both coerced and opportunistic young recruits rewarded by loot, which "diminished its core commanders' capacity to monitor, discipline, and control local commanders and foot soldiers" (Johnston 2008, 131). In addition, the RUF forces were boosted with socalled "sobels," or government soldiers who also occasionally participated in rebel hitandrun raids (Themnér 2011). Consequently, the conflict was accompanied by largescale human rights violations by all competing factions, which prompted international intervention from ECOWAS and UN peacekeepers.

Following attempts to initiate a peace process over many years that brought the demobilization of 3,183 excombatants in 1998, a peace agreement was signed in Lomé in July 1999. From October the same year until April 2000, some 17,500 soldiers were demobilized in an U.N.led operation until it was disrupted by a renewed offensive by RUF in May. Their advance was stopped, and a ceasefire was agreed to in November 2000. The remaining forty thousand or so combatants were disarmed by January 2002 and offered reintegration assistance for another two years (Tesfamichael, Ball and Nenon 2004). ${ }^{6}$ However, a crucial consequence of the 2000 fighting was that RUF lost the political influence it had been provided in the powersharing stipulations in the earlier peace the agreement struck while the leaders of the movement were detained (Binningsb $\varnothing$ and Dupuy 2009). Despite multiple security crises in the country in the fol-

\footnotetext{
${ }^{6}$ In total, it is estimated that somewhere between 56,000 and 69,000 combatants were demoblized. The official figure is 71,043 but some were probably counted twice and some civilians pretended to be combatants (Themnér 2011).
} 
lowing years, the UN considered the situation sufficiently stable to withdraw peacekeepers in December 2005.

The principal-agent dilemma in Sierra Leone did not lead to conflict recurrence in the same country, but many demobilized combatants were instead recruited to fight across the border in Liberia. As war was winding down in Sierra Leone, there was growing political instability in Liberia. The former rebel leader Charles Taylor had been elected president in 1997, but his regime was under threat three years later. A new rebel group called Liberians United for Reconstruction and Democracy (LURD) had appeared in the northern part of the country and government forces were on the defensive (Reno 2011). As violence escalated, both Taylor's government and LURD launched campaigns to enlist demobilized combatants in Sierra Leone from May 2001 onward. Former RUF members were the most receptive to such overtures as they found themselves politically and economically marginalized and at great risk for revenge attacks from civilians and local police after demobilization (Themnér 2011). Demobilization removed many of the security and economic networks that had protected them during the conflict, and the postconflict government was unwilling to replace them through effective policing. Consequently, several thousand former RUF members were recruited to fight for the Liberian government forces in the years that followed. In many cases, they continued to serve in the same small units that they had in Sierra Leone, meaning that rerecruitment offered money, camaraderie, and security (Call 2010; Themnér 2013). Notably, they were in many cases fighting against their former opponents and fellow Sierra Leoneans in the subsequent war as LURD managed to recruit among many former antiRUF militia members (CDF). In the words of Themnér $(2013,320)$ : "when confronted with the option of joining either LURD's or Taylor's forces, exCDF and RUF combatants sought to minimize the threat to their own personal security by fighting for the entrepreneurs of violence they knew rather than actors who had a history of supporting their former opponents."

\section{Conclusion}

After civil conflict, a society is at greater risk for renewed conflict than countries without a history of civil war. One cannot assume from this, however, that a recurrence of violence is a direct continuation of the initial civil conflict, undertaken for the same reasons, and with the same actors. This study has shown that during the first decade after the end of civil conflict, there is an equal risk of an eruption of new rebellion involving new actors with new grievances as there is of the old groups of combatants taking up arms to fight over the same issues as spurred the initial civil conflict. After a decade of peace, a new rebellion is the most common threat of warfare in a postconflict society. 
This is logical, as the policies in a postconflict country aim to implement a peace settlement or reimpose state control to undermine the ability of former rebel elites to control their followers. A rank and file that disagrees with the decision to end fighting can form new groups or join other competing movements without much risk of punishment when their leaders commit to end the use of violence. This process affects both rebel recruits that are primarily ideologically motivated, like in the Shan states of Myanmar, and for whom economic rewards are more prominent incentives for recruitment such as in Sierra Leone. Of the three different relational challenges in postconflict societies that can spur a new conflict, only the breakdown of government-rebel elite relations involves a resumption of fighting between former foes. The other two, dissolution of rebel cohesion and failure of the peacetime government to establish trust with the former rebel supporters, depend upon intragroup dynamics within and among the pro and antigovernment factors in the initial civil conflict.

Analyzing the recurrence of civil conflict using disaggregated data about who is involved in a recurrence of fighting, this study finds that the effect of many of the policies promoted in peacebuilding is conditional. Different forms of negotiated settlements increase peace duration only for those who sign the agreement, but may also increase the risk of new rebellions. Victories reduce both the risk of conflict involving old rebels and new groups, but that relationship is influenced by the shorter duration of civil wars that end with a victory compared to other outcomes. The finding that stands out most in the statistical analysis is the lingering negative effects of multiple actors (rebel groups, but particularly progovernment militias) on postconflict societies and the influence of state repression on increasing the risk of renewed fighting in postconflict countries.

The analysis of the conflicts in Myanmar and Sierra Leone speak to the plausibility of the argument that a breakdown of rebel elites' control of their forces makes these former subordinates join other rebel groups. In both of these cases - following a ceasefire and a formal demobilization process, respectively - excombatants were willing to leave the group they fought with in the initial civil conflict and join another in the postconflict society. In addition, both cases show that this process of reconfiguration and remobilization was not a purely individual undertaking, but was often conducted by groups of excombatants allowing them to remain inside the trust networks for the security, economy, and camaraderie that they had relied on earlier in the conflict.

The implications of this research for future academic studies and policy are twofold. First, civil war recurrence should be reconceptualized as a process that may involve new rebels and new rebellions forming and not just focus on managing relations between former foes. Second, there is a need for greater focus on the processes by which trust networks formed during an initial conflict become embedded (or not) within postconflict governance structures, as they may shed light on tensions within reformed governments that threaten a sustainable peace. The best means for achieving a durable and stable rene- 
gotiated state-citizen contract are probably by ensuring repeated interactions between state institutions and exrebel constituents aimed at listening to, as well as providing support to help the problems that these communities face after demobilization. 


\section{References}

Atlas, Pierre M and Roy Licklider. 1999. "Conflict among former allies after civil war settlement: Sudan, Zimbabwe, Chad, and Lebanon." Journal of Peace Research 36(1):35-54.

Autesserre, Séverine. 2010. The trouble with the Congo: Local violence and the failure of international peacebuilding. Cambridge University Press.

Balcells, Laia and Stathis N Kalyvas. 2014. "Does warfare matter? Severity, duration, and outcomes of civil wars." Journal of Conflict Resolution 58(8):1390-1418.

Binningsb $\varnothing$, Helga Malmin and Kendra Dupuy. 2009. "Using power-sharing to win a war: The implementation of the Lomé Agreement in Sierra Leone." Africa Spectrum pp. 87-107.

BNI, Burma News International. 2013. Deciphering Myanmar's Peace Process: A reference guide 2013. Burma News International: Chiang Mai.

BNI, Burma News International. 2015. Deciphering Myanmar's Peace Process: A reference guide 2015. Burma News International: Chiang Mai.

Boyle, Michael J. 2014. Violence after war: explaining instability in post-conflict states. JHU Press.

Butler, Christopher K, Tali Gluch and Neil J Mitchell. 2007. "Security Forces and Sexual Violence: A Cross-National Analysis of a Principal-Agent Argument." Journal of Peace Research 44(6):669-687.

Call, Charles T. 2010. "Liberia's war recurrence: Grievance over greed." Civil Wars 12(4):347-369.

Call, Charles T and William Stanley. 2001. "Protecting the people: Public security choices after civil wars." Global Governance 7(2):151-172.

Caplan, Richard and Anke Hoeffler. 2017. "Why peace endures: an analysis of post-conflict stabilisation." European Journal of International Security $2(2): 133-152$.

Carey, Sabine C, Michael P Colaresi and Neil J Mitchell. 2015. "Governments, Informal Links to Militias, and Accountability." Journal of Conflict Resolution pp. 850-876.

Carey, Sabine C, Neil J Mitchell and Will Lowe. 2013. "States, the security sector, and the monopoly of violence: A new database on pro-government militias." Journal of Peace Research 50(2):249-258.

Carter, David B and Curtis S Signorino. 2010. "Back to the future: Modeling time dependence in binary data." Political Analysis 18(3):271-292. 
Cederman, Lars-Erik, Kristian Skrede Gleditsch and Halvard Buhaug. 2013. Inequality, grievances, and civil war. Cambridge University Press.

Cunningham, Kathleen Gallagher, Kristin M Bakke and Lee JM Seymour. 2012. "Shirts today, skins tomorrow: Dual contests and the effects of fragmentation in self-determination disputes." Journal of Conflict Resolution 56(1):67-93.

Dahlberg, Stefan, Soren Holmberg, Bo Rothstein, Felix Hartmann and Richard Svensson. 2015. "The Quality of Government Basic Dataset, version Jan15, 2015.". University of Gothenborg: The Quality of Government Institute.

de Rouen Jr, Karl R and David Sobek. 2004. "The dynamics of civil war duration and outcome." Journal of Peace Research 41(3):303-320.

DeRouen Jr, Karl, Jenna Lea and Peter Wallensteen. 2009. "The duration of civil war peace agreements." Conflict Management and Peace Science 26(4):367-387.

DeRouen, Karl R and Jacob Bercovitch. 2008. "Enduring internal rivalries: A new framework for the study of civil war." Journal of Peace Research $45(1): 55-74$.

Driscoll, Jesse. 2012. "Commitment problems or bidding wars? Rebel fragmentation as peace building." Journal of Conflict Resolution 56(1):118-149.

DVB, Democratic Voice of Burma. 2013. "Armed group claims military attacking sites slated for resettlement.". February 25, 2013.

Eisenhardt, Kathleen M. 1989. "Agency theory: An assessment and review." Academy of management review 14(1):57-74.

Fariss, Christopher J. 2014. "Respect for human rights has improved over time: Modeling the changing standard of accountability." American Political Science Review 108(02):297-318.

Fine, Jason P and Robert J Gray. 1999. "A proportional hazards model for the subdistribution of a competing risk." Journal of the American statistical association 94(446):496-509.

Fortna, Virginia Page. 2004. Peace time: Cease-fire agreements and the durability of peace. Princeton University Press.

Gates, Scott. 2002. "Recruitment and allegiance: The microfoundations of rebellion." Journal of Conflict resolution 46(1):111-130.

Gleditsch, Kristian Skrede. 2002. "Expanded trade and GDP data." Journal of Conflict Resolution 46(5):712-724.

Gleditsch, Nils Petter, Peter Wallensteen, Mikael Eriksson, Margareta Sollenberg and Håvard Strand. 2002. "Armed conflict 1946-2001: A new dataset." Journal of peace research 39(5):615-637. 
Hartzell, Caroline A. 2009. "Settling civil wars: Armed opponents' fates and the duration of the peace." Conflict Management and Peace Science 26(4):347365 .

Hartzell, Caroline and Matthew Hoddie. 2003. "Institutionalizing Peace: Power Sharing and Post-Civil War Conflict Management." American Journal of Political Science 47(2):318-332.

Hogbladh, Stina, Thérese Pettersson and Lotta Themnér. 2011. "External support in Armed Conflict 1975-2009 - Presenting new data.". Presented at the International Studies Convention in Montreal.

Interview. 2010. "SSA-N member.". April, 2010.

Interview. 2011a. "Colonel Sao Sai Htoo, Spokesperson of SSA-N.". December, 2011.

Interview. 2011b. "SSA-N member.". April, 2011.

Interview. 2012a. "Frontline colonel, SSA-N." . April, 2012.

Interview. 2012b. "Shan rebel soldier.". October, 2012.

Interview. 2012c. "Shan rebel soldier.". November, 2012.

Interview. 2012d. "Statement of villager.". April, 2012.

Interview. 2013. "Rebel soldier.". January, 2013.

Jha, Saumitra and Steven Wilkinson. 2012. "Does combat experience foster organizational skill? Evidence from ethnic cleansing during the partition of South Asia." American Political Science Review 106(4):883-907.

Johnston, Patrick. 2008. "The geography of insurgent organization and its consequences for civil wars: evidence from Liberia and Sierra Leone." Security Studies 17(1):107-137.

Kalyvas, Stathis N. 2003. "The ontology of "political violence": action and identity in civil wars." Perspectives on Politics 1(03):475-494.

Karlén, Niklas. 2017. "The legacy of foreign patrons: External state support and conflict recurrence." Journal of Peace Research pp. 499-512.

Kecskemeti, Paul. 1958. Strategic Surrender. RAND Corporation.

Kreutz, Joakim. 2010. "How and when armed conflicts end: Introducing the UCDP Conflict Termination dataset." Journal of Peace Research 47(2):243250 .

Kydd, Andrew and Barbara F Walter. 2002. "Sabotaging the peace: The politics of extremist violence." International Organization 56(2):263-296. 
Levi, Margaret. 1997. Consent, dissent, and patriotism. Cambridge University Press.

Lichbach, Mark Irving. 1987. "Deterrence or escalation? The puzzle of aggregate studies of repression and dissent." Journal of Conflict Resolution 31(2):266297.

Licklider, Roy. 1995. "The consequences of negotiated settlements in civil wars, 1945-1993." American Political science review 89(3):681-690.

Lin, Danyu Y and Lee-Jen Wei. 1989. "The robust inference for the Cox proportional hazards model." Journal of the American statistical Association 84(408):1074-1078.

Lintner, Bertil. 1999. Burma in revolt: Opium and insurgency since 1948. Silkworm books: Chiang Mai.

Long, J Scott and Jeremy Freese. 2006. Regression models for categorical dependent variables using Stata. Stata press.

Mampilly, Zachariah Cherian. 2011. Rebel rulers: Insurgent governance and civilian life during war. Cornell University Press.

Marshall, Monty G, Keith Jaggers and Ted Robert Gurr. 2014. "Polity IV Annual Time-Series, 1800-2013." Center for International Development and Conflict Management at the University of Maryland College Park .

Mason, David T, Mehmet Gurses, Patrick T Brandt and Jason Michael Quinn. 2011. "When civil wars recur: conditions for durable peace after civil wars." International Studies Perspectives 12(2):171-189.

Mason, T David and Patrick J Fett. 1996. "How civil wars end: A rational choice approach." Journal of Conflict Resolution 40(4):546-568.

Matanock, Aila M and Miguel García-Sánchez. 2017. "The Colombian Paradox: Peace Processes, Elite Divisions \& Popular Plebiscites." Daedalus pp. 152166.

Mitchell, Neil. 2004. Agents of atrocity: Leaders, followers, and the violation of human rights in civil war. Springer.

Nilsson, Desirée. 2008. "Partial peace: Rebel groups inside and outside of civil war settlements." Journal of Peace Research 45(4):479-495.

Nussio, Enzo and Ben Oppenheim. 2014. "Anti-social capital in former members of non-state armed groups: A case study of Colombia." Studies in Conflict \& Terrorism 37(12):999-1023.

Nygård, Håvard Mokleiv and Michael Weintraub. 2015. "Bargaining between rebel groups and the outside option of violence." Terrorism and Political Violence 27(3):557-580. 
Olson Lounsbery, Marie and Alethia H Cook. 2011. "Rebellion, mediation, and group change: An empirical investigation of competing hypotheses." Journal of Peace Research 48(1):73-84.

Pearlman, Wendy. 2009. "Spoiling inside and out: Internal political contestation and the Middle East peace process." International Security 33(3):79-109.

PWO, Palaung Women's Organization. 2013. "Update of human right violations by Burma Army during offensives in Palaung areas, March and April 2013.". April 6, 2013.

Quinn, J Michael, T David Mason and Mehmet Gurses. 2007. "Sustaining the peace: Determinants of civil war recurrence." International Interactions 33(2):167-193.

Reiter, Andrew G. 2016. Fighting Over Peace: Spoilers, Peace Agreements, and the Strategic Use of Violence. Springer.

Reno, William. 2011. Warfare in independent Africa. Cambridge University Press.

Richards, Paul. 1996. Fighting for the rainforest: War, youth and resources in Sierra Leone. James Currey.

Ross, Michael. 2012. The oil curse: how petroleum wealth shapes the development of nations. Princeton University Press.

Rudloff, Peter and Michael G Findley. 2016. "The downstream effects of combatant fragmentation on civil war recurrence." Journal of Peace Research 53(1):19-32.

Saideman, Stephen M and Marie-Joëlle Zahar. 2008. Causing Security, Reducing Fear: Deterring Intra-State Violence and Assuring Government Restraint. In Intra-State Conflict, Governments and Security: Dilemmas of Deterrence and Assurance, ed. Stephen M Saideman and Marie-Joëlle Zahar. Routledge.

Sanín, Francisco Gutiérrez and Elisabeth Jean Wood. 2014. "Ideology in civil war: Instrumental adoption and beyond." Journal of Peace Research $51(2): 213-226$.

Shoke, Maung Pho. 1999. Why did U Khun Sa's MTA exchange arms for peace. Meik Kaung Press: Yangon.

Small, Kenneth A and Cheng Hsiao. 1985. "Multinomial logit specification tests." International economic review pp. 619-627.

Staniland, Paul. 2014. Networks of rebellion: Explaining insurgent cohesion and collapse. Cornell University Press.

Stedman, Stephen John. 1997. "Spoiler problems in peace processes." International security 22(2):5-53. 
Tesfamichael, Gebreselassie, Nicole Ball and Julie Nenon. 2004. Peace in Sierra Leone: evaluating the disarmament, demobilization, and reintegration process. Creative Associates International, Washington, DC.

Themnér, Anders. 2011. Violence in post-conflict societies: Remarginalization, remobilizers and relationships. Routledge.

Themnér, Anders. 2013. "A leap of faith: When and how ex-combatants resort to violence." Security Studies 22(2):295-329.

Themnér, Lotta and Peter Wallensteen. 2014. "Armed conflicts, 1946-2013." Journal of Peace Research 51(4):541-554.

Tilly, Charles. 2005. Trust and rule. Cambridge University Press.

Toft, Monica Duffy. 2010. "Ending Civil Wars: A Case for Rebel Victory?" International Security 34(4):7-36.

Tun, Sai Aung. 2009. History of the Shan State since its origins to 1962. Silkworm Books; Chiang Mai.

Vinci, Anthony. 2006. "The" problems of mobilization" and the analysis of armed groups." Parameters 36(1):49-62.

Vogt, Manuel, Nils-Christian Bormann, Seraina Rüegger, Lars-Erik Cederman, Philipp Hunziker and Luc Girardin. 2015. "Integrating data on ethnicity, geography, and conflict: The ethnic power relations data set family." Journal of Conflict Resolution 59(7):1327-1342.

Walter, Barbara F. 2002. Committing to peace: The successful settlement of civil wars. Princeton University Press.

Walter, Barbara F. 2009. "Bargaining failures and civil war." Annual Review of Political Science 12:243-261.

Walter, Barbara F. 2015. "Why bad governance leads to repeat civil war." Journal of Conflict Resolution 59(7):1242-1272.

Weinstein, Jeremy M. 2006. Inside rebellion: The politics of insurgent violence. Cambridge University Press.

Werner, Suzanne. 1999. "The precarious nature of peace: Resolving the issues, enforcing the settlement, and renegotiating the terms." American Journal of Political Science pp. 912-934.

Zeigler, Sean M. 2015. "Competitive Alliances and Civil War Recurrence." International Studies Quarterly 60(1):24-37. 